\title{
Roadmap to inculcate complex problem-solving skills in CS/IT students
}

\author{
Amol C. Adamuthe ${ }^{1}$, Manoj A. Patil ${ }^{2}$ \\ ${ }^{1,2}$ Dept. of CS\&IT, Rajarambapu Institute of Technology, Rajaramnagar \\ amol.admuthe@gmail.com \\ ²manoj.patil@ritindia.edu
}

\begin{abstract}
IT industries expect critical \& analytical thinking, programming skills, domain \& technology knowledge and soft skills from CS/IT graduates. There is a need for investigation of outcome-based methods to inculcate complex problem-solving skills among graduates. This paper presents a roadmap for designing student learning outcomes, assessment methods, curriculum and active teaching-learning activities for CS/IT programme. The proposed roadmap incorporates project-based, problem-based and case study based teaching-learning and assessment strategies to address higher Bloom's level. The proposed roadmap of implemented for the 201519 batch of CS\&IT department, Rajarambapu Institute of Technology. The case study presents identified 13 student learning outcomes (SLOs) in line with program outcomes and current IT industry expectations. To achieve the SLOs, problem and project-based assessment methods and teachinglearning methods are designed. To calculate the success of the proposed roadmap, students' performance of 2015-19 batch is compared with ancestor batch 2014-18. The effectiveness of the proposed roadmap for inculcating complex problem solving is measured with percentage of higher levels of Bloom's addressed in assessment, attainment of student learning outcomes, attainment of students'
\end{abstract}

\footnotetext{
Amol C. Adamuthe

Dept. of CS\&IT,

Rajarambapu Institute of Technology, Rajaramnagar

amol.admuthe@gmail.com
}

employability skills and student's feedback. For all courses, performance of students of batch 2015-19 is better than batch 2014-18. The better performance is shown with highest and median marks. Batch 2015-19 shows better student learning outcomes and employability scores than batch 2014-18. The proposed roadmap is found better on all mentioned measures for inculcating complex problem-solving skills.

Keywords: Problem-solving roadmap, project-based learning, problem-based learning, outcome-based education.

\section{Introduction}

National Employability report 2019 published a survey conducted for 170,000 students from 750 engineering colleges in India. According to this report, more than $90 \%$ students are weak in problemsolving skills such as algorithmic knowledge, programming, analytical skills, etc. Research in Education System has reported the limitation of traditional teaching-learning and evaluation methods. Lack of patience in young generation drives the need for active teaching-learning methods. So, it's time to update and improve the teaching \& assessment process through activity-based learning and active learning techniques.

In literature different active learning techniques are investigated for student's engagement. Few popular active teaching-learning methods are projectbased learning, think pair share, case study based 
learning, flipped classroom. The main motive behind these techniques is to improve, student's engagement in the classroom, solving complex problems, selflearning, lifelong learning and collaborative work. In literature, problem-based learning technique is used for different disciplines such as medical, law, engineering. The authors have presented the effectiveness of project-based and problem-based learning in engineering education. They have clarified the difference between two methods and review in engineering education (Mills et al., 2003).

Many researchers reported the advantages of problem-based learning methods (Ellis et al., 1998; Evensen et al., 2000; Kay et al., 2000; Fee \& HollandMinkley, 2010). The authors reviewed problem-based learning by collecting data through interactions and discussions with students for positive lines of research. They have used this data for curriculum decisions and supervisor practice. (Evensen et al., 2000). Paper presented PBL approach for planning to evaluation for courses in computer science. The authors shared their experience in PBL implementation (Kay et al., 2000). Paper presented the impact of PBL method on undergraduate Electrical Engineering course. The study validates effectiveness of PBL method (Yadav et al., 2011).

Project-based learning promotes students for effective learning by doing. This is a most active method of learning which allows a student to demonstrate his or her skills while working independently, and it develops the leadership skills to work with his or her peers, building teamwork and group skills (Chinnowsky et al., 2006; Hung et al., 2012; Holmes \& Hwang, 2016). Paper presented the implementation of PBL for two courses in Mechanical Engineering. The authors reported the integration of PBL in engineering curriculum. PBL method is gaining interest in engineering education (Hadim \& Esche, 2002). The authors presented experimental learning by changing teaching style from a theorybased to a project-based. PBL tested the students' ability with open-ended challenges. PBL courses have been introduced at the Colorado University and Student feedbacks are taken to identify the possible benefits this approach (Chinowsky et al., 2006). The authors presented students' perceptions regarding PBL implementation and its impact on a course in Mechanical Engineering taught using project-based learning. Students are expected to complete miniproject under selected course. Paper presents an analysis of PBL as learning environment using teachers, assistants and students involved in the course (Frank et al., 2003). The authors presented the advantages of PBL methodology for a course related to Computer Education. Authors reported that the PBL method is strongly associated with real life scenario and found effective despite of lack of resources (Gülbahar \& Tinmaz, 2006).

Case study based teaching and learning can engage students enthusiastically to apply skills to study and analyse real-world problems/situations. This method can be used to enhance students learning by experimenting between theories and come up with new ideas or alternate solutions (Mustoe \& Croft, 1999; Raju \& Sankar, 1999; Yadav, 2007; Popil 2011).

In literature, problem-based and project-based learning methods are investigated for a single course in engineering education. To the best of our knowledge, no single paper is available which deals with multiple courses of CS/IT programme. This paper presents a roadmap for improving problemsolving skills of CS/IT students using problem and project-based assessment and active learning methods. The presented roadmap is helpful for design, delivery and assessment of multiple courses of CS/IT programme. The main objective of this paper is to improve student's ability to integrate knowledge and skills from different courses/domains to analyse, evaluate, design and develop solutions to complex engineering or real-world problem effectively.

Important contributions of the paper are,

- It provides the outcome-based education plan for complete three years span of the CS/IT undergraduate programme.

- The proposed roadmap follows an inductive methodology for OBE activities. It helps for designing curriculum, student learning outcomes (SLOs), problem/project based learning, assessment methodology. Proposed roadmap address the dependency between the student learning outcomes from different courses. The student learning outcomes address higher level of Bloom's taxonomy in incremental mode.

- The proposed roadmap is applied to 2015-19 batch of CS\&IT department, RIT. Paper presents case study of CS\&IT department with shortlisted important student learning outcomes, courses, learning methods, assessment methods and evaluation rubrics. Students' performance of 201519 batch is compared with ancestor batch 2014-18. 
The effectiveness of proposed roadmap is presented with attainment of course outcomes, course results, students' employability skills and students' feedback.

The remaining paper is divided as follows. Section 2 presents the proposed roadmap and case study. Section 3 is about the results and discussion of outcomes and observations of the proposed roadmap. The conclusion is given in section 4 .

\section{Proposed Roadmap and Case study}

This section provides the roadmap for strengthening problem-solving skills of CS/IT students. To improve the problem-solving skills of CS/IT student's improvement in the entire teachinglearning environment is necessary. Paper presents an inductive methodology to enhance students learning. The proposed roadmap covers course outcomes, active teaching-learning environment and assessment methodologies. The proposed roadmap is applicable to all engineering programme.

Four steps of the proposed roadmap are as below,

Step 1: Design student learning outcomes (SLO)

Step 2: Design assessment methods for each SLO

Step 3: Develop a curriculum

Step 4: Design active teaching-learning methods

Head of department, academic monitor and course in charge have very role important in the implementation of the proposed roadmap.

- Head of Department (HOD) has the main role to design, customize and implement the roadmap. HOD is responsible for planning and designing the first three steps of roadmap. He/she should identify the student learning outcomes for better problems o lving and increasing the employability/entrepreneurship. The curriculum should be in line with outcomes and current/future industry requirements in local and global. HOD is responsible to ensure high-quality standards in teaching-learning practices and assessments in department. HOD needs to ensure all activities are practicing at highest possible standards and following the necessary evaluation and monitoring procedures.
- The academic monitor has a responsibility to continuously monitor the teaching activities in line with the plans. To improve the teaching-learning activities, HOD and academic monitor will take a weekly review of respective courses based on active learning techniques used to teach the course, evaluation techniques used to assess the students and taking follow up for students learning.

- The course in-charge responsible to prepare an activity-based course plan for effective delivery of course content during the teaching. Course incharge is also responsible to use the active learning-based evaluation of students instead of traditional methods and ensure the students learning by taking feedback from students about their learnings.

\section{A. Design student learning outcomes}

This step gives procedure to design important student learning outcomes required to improve the student's problem-solving skills. SLO describes the problem-solving knowledge and skills students expected to learn. The SLOs must address and in line with program outcomes and employability skills requirements of programme. The main objective is to improve student's ability to integrate knowledge and skills from different courses/domains to analyse, evaluate, design and develop solutions to complex engineering or real-world problem effectively.

Program outcomes represent the knowledge, skills and attitudes the students should have at the end of an engineering program. The first six program outcomes (POs) of department of Computer science and information technology, RIT are as given below.

- PO1: Application of fundamental knowledge of solve complex problems. It covers the fundamentals of science and engineering.

- PO2: Steps of problem identification to analysis are covered in second program outcome. Identification of problem from engineering discipline or real-world application in first important step. Correct problem formulation using suitable techniques is second step. Study of literature to understand different alternative solution and critical analysis of the problem in third step.

- PO3: It focus on development of IT service/product that satisfies the customer's need 
satisfying the environmental/legal/societal requirements. It needs the understanding of domain knowledge.

- PO4: It focus on core problem-solving skills and interpretation. It covers the students' ability to conduct the suitable experimentations/tests. Further, interpretation of observations/data to reach accurate conclusions is necessary.

- P O 5: Selection of suitable methodology/technique/tool for solving the complex problem is covered. Selection of suitable technique/tool from available pool to models, design and analysis is important tasks.

- PO6: Doing professional practices considering the contextual references including social, legal and safety needs/norms is addressed in this program outcome.

The IT industry expectations are understanding of,

- Fundamental courses

- Recent information technologies

- New software development industry

Based on the program outcomes and industry expectations, 13 student learning outcomes (SLO) are designed. Each SLO is mapped to multiple POs based on their influence. Table 1 shows the mapping of SLOs with POs. Here 'HI' indicates strong co-relation. Further, dependency between the SLOs is identified. Table 2 shows the dependency of SLO with other SLOs. Programming skills are pre-requisite for any CS/IT student. The proposed roadmap assumes that the fundamental knowledge of programming courses such as $\mathrm{C}, \mathrm{C}++$ and Java is satisfactory. In SLO 8, 9, 10,12 and 13 implicitly addresses the required programming skills such as python, PHP.

- SLO 1: Choose appropriate data structures for developing a solution to the problem.

- SLO_2: Analyse algorithm design techniques for solving the complex problem.

- SLO_3: Practice software process models for realworld problem.

- SLO_4: Apply the project management concepts for the real-world problem.
- SLO_5: Design software system models using UML.

- SLO_6: Draw E-R diagram and design database according to organizations' requirement.

- SLO_7: Write SQL and No-SQL queries to perform various operations on database for specific objectives.

- SLO 8: Design User Interfaces (UIs) for Android applications using controls, layout managers, menus and dialogs.

- SLO_9: Perform testing, packaging of mobile applications and deploy Android applications to emulators and physical devices.

- SLO_10: Build interactive web applications.

- SLO_11: Explore and identify different cloud platforms and services.

- SLO_12: Design and implement IoT solutions for real word problems.

- SLO 13 Applying appropriate tools and techniques for data analytics.

Table 1: SLO to PO mapping

\begin{tabular}{|l|l|l|l|l|l|l|}
\hline & PO1 & PO2 & PO3 & PO4 & PO5 & PO6 \\
\hline SLO_1 & HI & HI & HI & HI & & \\
\hline SLO_2 & HI & HI & HI & HI & & \\
\hline SLO_3 & HI & HI & HI & HI & & HI \\
\hline SLO_4 & HI & HI & HI & HI & & HI \\
\hline SLO_5 & HI & HI & HI & HI & HI & HI \\
\hline SLO_6 & HI & HI & HI & HI & HI & HI \\
\hline SLO_7 & HI & HI & HI & HI & HI & HI \\
\hline SLO_8 & HI & HI & HI & HI & HI & HI \\
\hline SLO_9 & HI & HI & HI & HI & HI & HI \\
\hline SLO_10 & HI & HI & HI & HI & HI & HI \\
\hline SLO_11 & HI & HI & HI & HI & HI & HI \\
\hline SLO_12 & HI & HI & HI & HI & HI & HI \\
\hline SLO_13 & HI & HI & HI & HI & HI & HI \\
\hline
\end{tabular}

Table 2: Dependancy between SLOs

\begin{tabular}{|l|l|}
\hline & Dependent on other SLOs \\
\hline SLO_10 & $\begin{array}{l}\text { SLO_1, SLO_2, SLO_3, SLO_4, SLO_5, SLO_6, } \\
\text { SLO_7 }\end{array}$ \\
\hline SLO_12 & $\begin{array}{l}\text { SLO_1, SLO_2, SLO_3, SLO_4, SLO_5, SLO_6, } \\
\text { SLO_7, SLO_8, SLO_9, SLO_10, SLO_11, }\end{array}$ \\
\hline
\end{tabular}


B. Design assessment methods for each SLO

This section presents the formative assessment methods for identified student learning outcomes. The main objective of the assessment method is to address higher Bloom's level. Higher Bloom's level address higher knowledge and skills level such as develop, formulate, solve, investigate, apply and demonstrate.

Table 3 shows the investigated assessment methods and addressed Bloom's level for student learning outcomes. The proposed assessment methods address the higher level of Bloom's Taxonomy i.e. application (level 3), analysis (level 4) and synthesis (level 5).

This section presents the assessment methodology adopted and implemented in department of CS\&IT, RIT.

1) Assessment methodology for project-based learning

The assessment methodology for project-based learning presented by (Adamuthe \& Mane, 2016) is used in this paper.

Identify suitable assessment methods in line with the course outcomes. Identify the assessment strategies covering all the objectives/outcomes and decide the weightage accordingly.

Table 3: Selected active learning-based assessment methods

\begin{tabular}{|c|c|c|c|}
\hline SLO & Assessment method & \multicolumn{2}{|c|}{$\begin{array}{l}\text { Addressed Bloom . } \\
\text { level }\end{array}$} \\
\hline SLO_1 & Problem-based & \multirow{2}{*}{\multicolumn{2}{|c|}{ Analysis, Application }} \\
\hline SLO_2 & Problem-based & & \\
\hline SLO_3 & $\begin{array}{l}\text { Problem-based, case } \\
\text { study based }\end{array}$ & \multirow{7}{*}{\multicolumn{2}{|c|}{$\begin{array}{l}\text { Synthesis, Analysis, } \\
\text { Application }\end{array}$}} \\
\hline SLO_4 & $\begin{array}{l}\text { Problem-based, case } \\
\text { study based }\end{array}$ & & \\
\hline SLO_5 & $\begin{array}{l}\text { Problem-based, Project- } \\
\text { based learning }\end{array}$ & & \\
\hline SLO_6 & \multirow[t]{4}{*}{ Project-based } & & \\
\hline SLO_7 & & & \\
\hline SLO_8 & & & \\
\hline SLO_9 & & & \\
\hline SLO_10 & \multirow[t]{3}{*}{ Project-based } & Application & \multirow[t]{4}{*}{ Synthesis } \\
\hline$\overline{\text { SLO_11 }}$ & & \multirow[t]{3}{*}{ Analysis } & \\
\hline SLO_12 & & & \\
\hline$\overline{S L O \_13}$ & Project-based & & \\
\hline
\end{tabular}

- Correlate the assessment methods to students' knowledge and skills levels. Assessment methods must focus on higher levels of Bloom's Taxonomy.

- Prepare the assignments/tasks/practicals with the required level of deliverables.

- Prepare assessment criteria/rubrics for each evaluation mode for measurement of outcomes/deliverables.

2)Assessment methodology for problem-based learning

- Identify and define the problem correctly

- Identify and connect the relevant topics/issues for given problem-solving

- Identify multiple solution strategies

- Evaluation of proposed solutions

- Presents accurate and clear argument for the given problem

3) Assessment methodology for case study

- Collect the relevant resource material

- Identify the problem

- Critical analysis of different solution strategies.

- Identify a suitable strategy/research gap/research direction.

Table 4 presents the project-based assessment plan for SLO_6 and SLO_7. The table 4 gives precise plan to evaluate individual students based on required parameters. This is a sample case example for database engineering course. The objective of this course is to design and develop database application for any organization.

A generic rubric-based assessment is shown in table 5. It is used to grade students' work as per the mentioned criteria. Rubrics based evaluation can also be called criteria sheets or grading schemes or scoring guides. It describes the levels of quality for each student based on criteria. Rubric-based assessment provides proper guidelines to the student and teacher to conduct meaningful assessments without any bias. 
Table 4: PBL based evaluation for Database Engineering course (Adamuthe \& Mane, 2016)

\begin{tabular}{|c|c|c|c|c|c|}
\hline $\begin{array}{l}\text { Sr. } \\
\text { No. }\end{array}$ & Outcomes & $\begin{array}{l}\text { Assessment } \\
\text { method (\% } \\
\text { weightage) }\end{array}$ & $\begin{array}{l}\text { Knowledge/skills } \\
\text { addressed }\end{array}$ & $\begin{array}{l}\text { Bloom's } \\
\text { Taxonomy } \\
\text { level }\end{array}$ & Assessment criteria \\
\hline 1 & $\begin{array}{l}\text { - Interact with different } \\
\text { enterprises where DBMS is } \\
\text { necessary. } \\
\text { - Identify the need for DBMS } \\
\text { and finalize the objectives of } \\
\text { the system. } \\
\text { - Design a DBMS system } \\
\text { satisfying the objectives/needs } \\
\text { of an enterprise. }\end{array}$ & $\begin{array}{l}\text { Design } \\
\text { Document (40\% } \\
\text { weightage) }\end{array}$ & $\begin{array}{l}\text { - } \text { Knowledge of } \\
\text { respective industry } \\
\text { - Application of software } \\
\text { development process } \\
\text { - Communication skills } \\
\text { - Professional ethics } \\
\text { - Use of modern tools and } \\
\text { techniques }\end{array}$ & $\begin{array}{l}\text { Application } \\
\text { (Level 3) } \\
\text { Synthesis } \\
\text { (Level 5) }\end{array}$ & $\begin{array}{ll}\text { - } & \text { Interaction with } \\
\text { end-user } \\
\text { - } & \text { Domain } \\
\text { knowledge } \\
\text { - } & \text { Use of ER } \\
\text { diagram constructs } \\
\text { - } \\
\text { Use of open - } \\
\text { source tool }\end{array}$ \\
\hline 2 & $\begin{array}{l}\text { Design and implementation of } \\
\text { database system with relational } \\
\text { database management tool }\end{array}$ & $\begin{array}{l}\text { Implementation } \\
\text { using SQL } \\
\text { (30\% weightage) }\end{array}$ & $\begin{array}{ll}- & \text { Problem-solving } \\
\text { - } & \text { Software development } \\
\text { process } \\
\text { - Use of modern and } \\
\text { open-source tools }\end{array}$ & $\begin{array}{l}\text { Application } \\
\text { (Level 3) }\end{array}$ & $\begin{array}{ll}- & \text { Database schema } \\
\text { - } & \text { SQL queries as per } \\
& \text { objectives } \\
- & \text { Use of SQL } \\
\text { constructs }\end{array}$ \\
\hline 3 & $\begin{array}{l}\text { Implement database application for } \\
\text { any individual/organization. }\end{array}$ & $\begin{array}{l}\text { Implementation } \\
\text { using Microsoft } \\
\text { Access } \\
\text { (30\% weightage) }\end{array}$ & & $\begin{array}{l}\text { Application } \\
\text { (Level 3) }\end{array}$ & $\begin{array}{ll}\text { - } & \text { Backend design as } \\
& \text { per objectives } \\
\text { - } & \text { Front end design } \\
\text { - } & \text { Connectivity of } \\
& \text { front end and back } \\
\text { end }\end{array}$ \\
\hline
\end{tabular}

Table 5: Generic criteria for evaluation of project-based learning

\begin{tabular}{|c|c|c|c|c|c|}
\hline \multirow{2}{*}{$\begin{array}{l}\text { Sr. } \\
\text { No. }\end{array}$} & \multirow{2}{*}{ Criteria } & \multicolumn{4}{|c|}{ Level of Attainment } \\
\hline & & Poor & Satisfactory & Good & Excellent \\
\hline 1 & $\begin{array}{l}\text { Identify area, sub-area } \\
\text { and topic }\end{array}$ & $\begin{array}{l}\text { Identified area, sub-area } \\
\text { and topic are not } \\
\text { relevant. }\end{array}$ & $\begin{array}{l}\text { Identified domain relevant } \\
\text { to current trends / } \\
\text { fundamental question. }\end{array}$ & $\begin{array}{l}\text { - Identified domain } \\
\text { relevant to current } \\
\text { trends/fundamental } \\
\text { question. } \\
\text { - Identified correct sub - } \\
\text { area. }\end{array}$ & $\begin{array}{l}\text { Identified topic/problem } \\
\text { is conceptually correct } \\
\text { and uses correct technical } \\
\text { terminology. }\end{array}$ \\
\hline 2 & $\begin{array}{l}\text { Depth of literature } \\
\text { review }\end{array}$ & $\begin{array}{l}\text { - Insufficient papers are } \\
\text { selected. } \\
\text { - Identified papers are } \\
\text { not from good } \\
\text { journals. }\end{array}$ & $\begin{array}{l}\text { - Selected a good number } \\
\text { of papers from standard } \\
\text { journals. } \\
\text { - Selected papers focus } \\
\text { on similar objectives. }\end{array}$ & $\begin{array}{l}\text { - A good number of } \\
\text { papers are reviewed. } \\
\text { - Written critical } \\
\text { comments. } \\
\text { - Identified research gap. }\end{array}$ & $\begin{array}{l}\text { - Identified more than } \\
\text { one research gap. }\end{array}$ \\
\hline 3 & $\begin{array}{l}\text { Problem statement and } \\
\text { objectives }\end{array}$ & $\begin{array}{l}\text { Problem statement and } \\
\text { objectives are not clear } \\
\text { and inline }\end{array}$ & $\begin{array}{l}\text { Identified problem } \\
\text { statement and objectives } \\
\text { are clear and inline }\end{array}$ & $\begin{array}{l}\text { Problem statements and } \\
\text { objectives are according } \\
\text { to the research gap }\end{array}$ & $\begin{array}{l}\text { Problem statements and } \\
\text { objectives address } \\
\text { multiple research gaps. }\end{array}$ \\
\hline 4 & Critical thinking & $\begin{array}{l}\text { Not analysed the } \\
\text { problem. }\end{array}$ & $\begin{array}{l}\text { Ambiguity in problem } \\
\text { analysis. }\end{array}$ & $\begin{array}{l}\text { Identified variation in } \\
\text { problem statements and } \\
\text { objectives. Compared to } \\
\text { different problem -solving } \\
\text { approaches. }\end{array}$ & $\begin{array}{l}\text { Done c ritical analysis of } \\
\text { the problem, objectives } \\
\text { and techniques. }\end{array}$ \\
\hline 5 & $\begin{array}{l}\text { Presentation Skills \& } \\
\text { Report Quality }\end{array}$ & $\begin{array}{l}\text { Poor PPT quality and } \\
\text { presentation skills } \\
\text { PPT / Report content is } \\
\text { incomplete or incorrect. }\end{array}$ & $\begin{array}{l}\text { Technical mistakes in the } \\
\text { content. } \\
\text { The report is not } \\
\text { technically correct and } \\
\text { comprehensive. }\end{array}$ & $\begin{array}{l}\text { Quality of PPT is good } \\
\text { and technically correct. } \\
\text { The report is technically } \\
\text { correct and } \\
\text { comprehensive }\end{array}$ & $\begin{array}{l}\text { Quality o f PPT is good } \\
\text { and technically correct. } \\
\text { Content is presented with } \\
\text { proper flow and } \\
\text { convincing skills } \\
\text { The report is technically } \\
\text { correct and } \\
\text { comprehensive } \\
\text { No grammatical mistakes } \\
\text { and typo errors in } \\
\text { presentation and report. }\end{array}$ \\
\hline
\end{tabular}


Table 6: Rubrics for Internetworking Protocol course

\begin{tabular}{|c|c|c|c|}
\hline & Poor & Average & Good \\
\hline $\begin{array}{l}\text { Concept map } \\
\text { preparation }\end{array}$ & $\begin{array}{l}\text { Concepts and } \\
\text { Ideas are } \\
\text { disconnected }\end{array}$ & $\begin{array}{l}\text { Concepts and } \\
\text { ideas are } \\
\text { somehow } \\
\text { inconsistent }\end{array}$ & $\begin{array}{l}\text { Concepts and } \\
\text { ideas are well } \\
\text { understood }\end{array}$ \\
\hline Demonstration & $\begin{array}{l}\text { Know the list } \\
\text { of } \\
\text { tools/services } \\
\text { to demonstrate } \\
\text { the concept. }\end{array}$ & $\begin{array}{l}\text { Service/tools } \\
\text { are just } \\
\text { installed, but } \\
\text { not able to } \\
\text { configure and } \\
\text { demo it }\end{array}$ & $\begin{array}{l}\text { Demonstrated } \\
\text { the } \\
\text { configuration of } \\
\text { service/ tool } \\
\text { along use or } \\
\text { application. }\end{array}$ \\
\hline$\overline{Q \& A}$ & $\begin{array}{l}\text { Unable to } \\
\text { answer. Most } \\
\text { of the answers } \\
\text { are wrong. }\end{array}$ & $\begin{array}{l}\text { Answer many } \\
\text { questions but } \\
\text { ambiguity in } \\
\text { few answers }\end{array}$ & $\begin{array}{l}\text { Handle difficult } \\
\text { questions easily } \\
\text { with confidence } \\
\text { and illustrative } \\
\text { explanation }\end{array}$ \\
\hline
\end{tabular}

It also helps to compare the achievement of the students to the desired outcomes designed for any course or content

Sample rubrics designed for Internetworking protocol course shown in table 6 .

Skill-based evaluation techniques motivate students to take projects rigorously to develop problem-solving, self-learning abilities and employability skills. Skill-based evaluation technique for academic projects actively engages students in project activity to achieve project deliverables. Students are asked to work in groups to gain other skills and knowledge which may not be taught in the classroom. Teachers are evaluating the students based on active learning techniques by considering criteria of outcomes of student learning. The methods invite the students to participate in the evaluation process, creating a student's friendly environment for learning and maintaining the fair transparency in assessment. The evaluation technique adds transparency in evaluation, justice to each student, differentiation in student skill wise.

\section{Develop curriculum}

We have developed the CS/IT curriculum by clearly defining student learning outcomes. The curriculum is designed to address the defined student learning outcomes and respective assessment strategies discussed in previous subsections. The curriculum focus on courses that have high priority for problemsolving skills. These 13 SLOs need to be addressed by multiple courses in three years of graduation span.
Table 7: Identified courses for selected SLOs

\begin{tabular}{|c|c|c|}
\hline $\begin{array}{l}\text { Student Learning } \\
\text { Outcomes (SLO) }\end{array}$ & Course name & Class \\
\hline SLO_1 & Data structures (DS) & Second year \\
\hline SLO_2 & Algorithms (Algo) & \multirow[t]{8}{*}{ Third year } \\
\hline SLO_3 & \multirow{2}{*}{$\begin{array}{l}\text { Software engineering } \\
\text { (SE) }\end{array}$} & \\
\hline SLO_4 & & \\
\hline SLO_5 & $\begin{array}{l}\text { Software modelling \& } \\
\text { design (SMD) }\end{array}$ & \\
\hline SLO_6 & \multirow[t]{2}{*}{ Database system (DB) } & \\
\hline SLO_7 & & \\
\hline SLO_8 & \multirow[t]{2}{*}{$\begin{array}{l}\text { Mobile application } \\
\text { development (MAD) }\end{array}$} & \\
\hline SLO_9 & & \\
\hline SLO_10 & $\begin{array}{l}\text { Web application } \\
\text { development (web) }\end{array}$ & \multirow[t]{4}{*}{ Final year } \\
\hline SLO_11 & Cloud computing (CC) & \\
\hline LO_12 & Internet of Things (IoT) & \\
\hline$\overline{S L O \_13}$ & Data analytics (DA) & \\
\hline
\end{tabular}

Table 7 presents the student learning outcome and identified courses.

- Data structures course includes elementary and advanced data structures namely stack, queues, linked lists, trees and graphs. It covers the basic operators and their applications to solve engineering and real-world problems.

- Algorithms introduces different algorithm design techniques and it's application. It covers P and NP problem-solving techniques.

- Software Engineering covers the software engineering process and models. It includes software design and management practices.

- Software Modelling \& Design course includes how to use object-oriented techniques to design software systems. The course starts with requirements gathering \& end with specific designs. In the process, student will learn static, dynamic and functional design of system.

- Database system course focuses on use of relational database management system for application development. It covers the fundamental concepts and query language.

- Mobile Application Development course 
introduces setting up Android app development environment (JDK, Android Studio, Android SDK), Android architecture, Tools in Android. Button, TextView, EditText, Spinner, ListView, RadioButton, etc. Layout in Android, Event delegation model in Android, Toast App. Activity, Service, Notification, Broadcast receiver, AlertDialog, Menus: Option Menu and Context Menu Native data handling: SQLite Database, Files handling and Shared Preferences. Signing and Packaging App: Signing, Packaging and Deploying Android app on Google Play store, Firebase demo, Mini project using Android.

- Web application development course focuses on design and development of Web-based applications using different programming languages and tools.

- Cloud computing course presents the journey of IT industry from mainframes to cloud computing. It covers the basic models and services of cloud computing. It focuses on technical and business aspects such as security, cloud services by leading vendors, application in healthcare and business, service level agreement, total cost of ownership.

- Internet of Things course address different hardware \& sensors required for data collection. It covers the IoT architectures, protocols and application to real-world problems.

- Data Analytics course covers methods and tools for analysing data from different domains such as marketing, finance. Topics include probability, statistics, clustering, classification and forecasting.

D. Design active teaching-learning methods

Skills-based students learning mainly focused on problem-based learning, project-based learning and case study based learning. Table 8 shows the active teaching-learning strategies used for selected courses.

- Problem-based learning

- Problem-based learning is mainly focused on student-centric education, in this student will learn a course through hands-on experience by trial and error to solve an open-ended problem that may found during the course study.

- Project-based Learning
- Project-based learning is a task-based approach where students are asked to apply the conceptual knowledge to develop a real-time application.

- Case study-based learning

- It focuses on applications, problem-solving methodology and practices.

Table 8: Active Teaching-Learning strategies adopted

\begin{tabular}{|c|c|}
\hline Course name & Teaching strategy \\
\hline Data structures (DS) & $\begin{array}{l}\text { - Problem-based learning } \\
\text { - Think pair share }\end{array}$ \\
\hline Algorithms (Algo) & $\begin{array}{l}\text { - Problem-based learning } \\
\text { - Think pair share }\end{array}$ \\
\hline Software engineering (SE) & $\begin{array}{l}\text { - Problem-based learning } \\
\text { - Jigsaw }\end{array}$ \\
\hline $\begin{array}{l}\text { Software modelling \& design } \\
\text { (SMD) }\end{array}$ & $\begin{array}{l}\text { - Project-based learning } \\
\text { - Jigsaw }\end{array}$ \\
\hline Database system (DB) & Project-based learning \\
\hline $\begin{array}{l}\text { Mobile application } \\
\text { development (MAD) }\end{array}$ & Project-based learning \\
\hline $\begin{array}{l}\text { Web application development } \\
\text { (web) }\end{array}$ & Project-based learning \\
\hline Cloud computing (CC) & Project-based learning \\
\hline Internet of Things (IoT) & Project-based learning \\
\hline Data analytics (DA) & Project-based learning \\
\hline
\end{tabular}

The sample problems selected for problem-based learning for course algorithms are as follows.

- Divide and conquer design technique is not applicable to solve TSP problem. Comment.

- Develop greedy algorithm to find minimum number of coins.

- Discuss the greedy strategy used in process scheduling algorithms: First come first serve and Round robin

- Discuss the greedy strategy used in bin packing algorithms: First fit and best fit.

- Illustrate the limitations of greedy method with graph colouring problem.

- What is the impact of state-space tree on performance of backtracking algorithm?

- Design effective solution representation for solving queen problem. 
Sample topics of project-based learning for mobile application development course are as follows,

- Village E-complaint management System

- Advertisement Reservation Application

- Nursery plant management system

- Student Feedback System

- Restaurant Management system

Sample topics of case study for Software Engineering and Software Modelling \& Design course are as follows.

- Vehicle Security system using IoT

- Citizen feedback system for road maintenance issues

- Nursery plant management system

- Water management system

- Chatbot for customer support system

Sample topics of project-based learning for Internet of Things course are as follows.

- Lab automation system

- Smart parking system

- An Intelligent System for Soil Analysis, nutrition management in Agriculture sector

- Smart street light control system

- Fire and smoke detection alarm system for mess

- IoT based garbage collection system

\section{Results and Discussion}

This section presents results of proposed roadmap implemented for batch 2015-19 of CS\&IT department, RIT. The results are compared with ancestor batch 2014-18 to which roadmap is not implemented. The comparison is done using the following measures. i) Percentage of higher levels of Bloom's addressed in assessment

ii) Attainment of student learning outcomes

iii) Attainment of students' employability skills

iv) Student's feedback

\section{A. Bloom's level addressed and SLO attainments}

To analyse the assessment quality and level of difficulty, total marks in each Bloom's level is calculated. The assessment covers ISE (in semester evaluation for 20 marks), unit tests (total 30 marks) and ESE (end semester evaluation for 50 marks). Figure 1 presents the percentage of evaluations addressing Bloom's level 1 to 3 and 4 to 6 . The 201519 batch in which roadmap is implemented shows more assessment percentage for Bloom's level 4 to 6 than 2014-18 batch. Courses adopted project-based learning (see table 8) addressed more than 50\% assessment in Bloom's level 4 to 6.

Figure 2 shows the comparison of courses adopted problem-based learning. The analysis is carried using marks obtained by all students. DS2014-18 indicates the marks of course data structures for 2014-18 batch. For data structure (DS) and software engineering (SE)

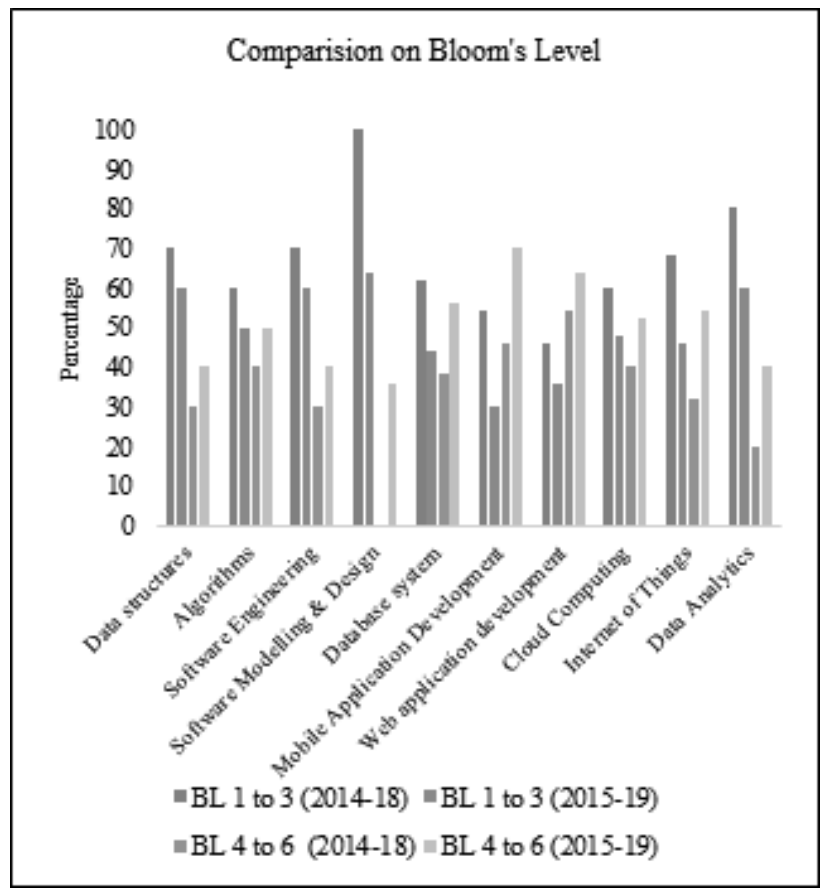

Fig. 1: Bloom's level addressed 


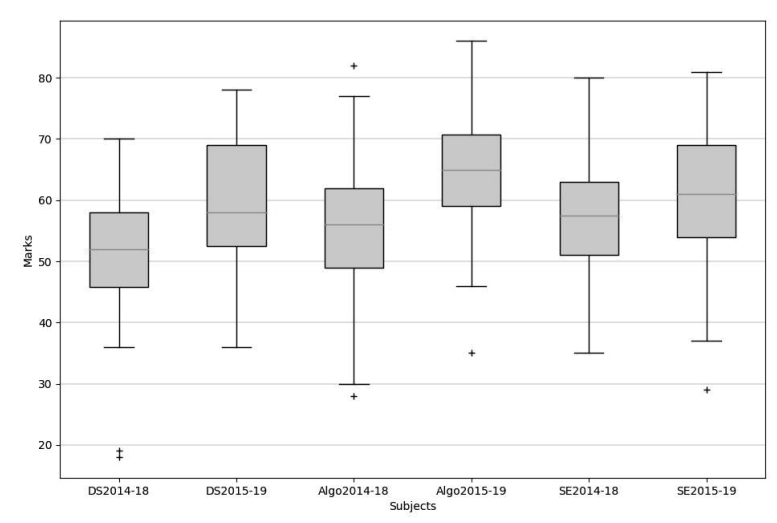

Fig. 2 : Comparision on courses with problem-based learning

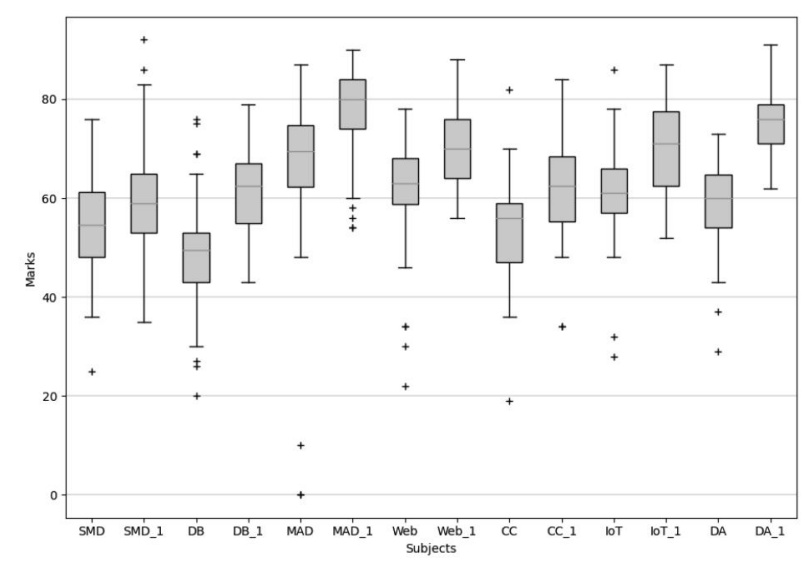

Fig. 3 : Comparision on courses with project-based learning

course the performance of students of batch 2015-19 is better than batch 2014-18. The better performance is achieved for obtained highest mark and median of marks. For algorithm (Algo) course the performance of batch 2015-19 is reduced significantly.

Figure 3 shows the comparison of courses adopted project-based learning. The analysis is carried using marks obtained by all students. SMD and SMD_1 indicates the marks of course Software modelling \& design for 2014-18 batch and 2015-19 batch respectively. For all course the performance of students of batch 2015-19 is better than batch 201418. The better performance is achieved for obtained highest mark and median marks.

Further, attainment of student learning outcomes is calculated using predefined threshold. Figure 4 presents the attainments of student learning outcomes. The course outcome attainment is calculated using the below formula.

Threshold based Attainment $\%=(\mathrm{x} / \mathrm{y}) * 100$

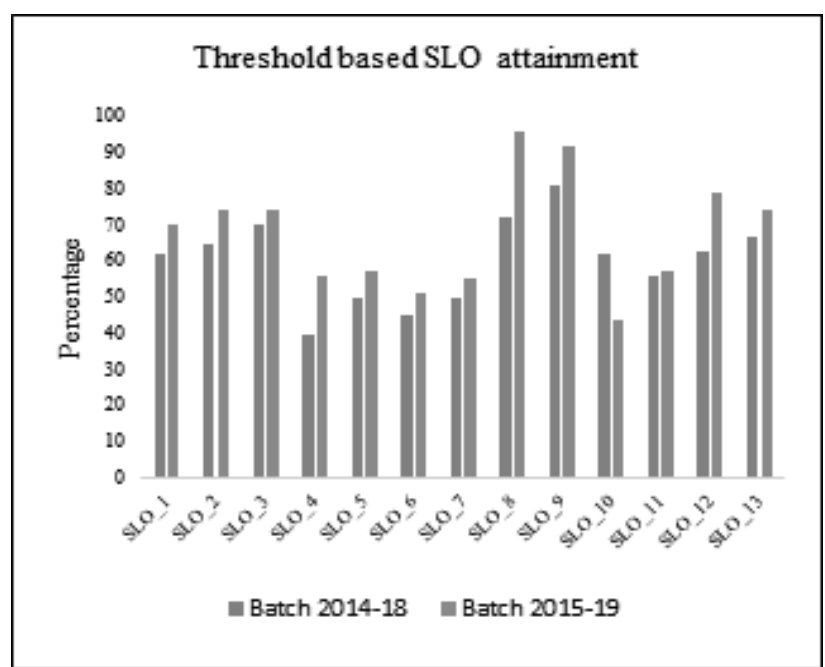

Fig. 4 : Attainment of student learning outcomes

$\mathrm{x}=$ Count of Students $>=$ to Threshold $\%$ $\mathrm{y}=$ Total number of students attempted.

Figures 4 shows that 2015-19 batch attainment is better than 2014-18 batch for all student learning outcomes except SLO_10.

Figure 4 shows that for batch 2015-19 attainment of two learning outcomes is more than $90 \%$. Attainment of five SLOs are more than $70 \%$. Student learning outcome attainment of SLO_8 and SLO_9 is regarding Mobile application Development. All students group have completed mobile application of social benefit and deployed on Google Play store [Google Play store]. SLO 12 is about the devolvement of IoT solutions for real word problems. High attainment is due to satisfactory completion on projects by majority of students. Student learning outcomes of SLO_10 is $44 \%$. The main reasons behind poor attainment are its dependency on other SLOs. To build interactive web application students should be able to choose appropriate data structures (SLO_1), analyse the different algorithm design it (SLO_2), should follow software engineering to design the blue-print models using UML diagrams (SLO_3 to SLO_5), design and write SQL and NoSQL query database according to organization requirement (SLO 6 to 7). After completion of each course, student's feedback is collected through seven questions.

\section{B. Employability skills}

Mandale \& Adamuthe (2019) presented methodology to evaluate students' employability skills. The focus is on identifying students' ability to integrate knowledge and skills from different courses. 
This technique is applied to evaluate students' performance at third-year mini-project and final year project course. Proposed evaluation technique focus on assessment of student's engineering skills, core skills, personal characteristics and communication skills at individual and group level. It evaluates student projects from all employability dimensions by considering innovative practices used in IT industry. The evaluation focus on three main skills listed in table 9.

Table 9: Employability skills

\begin{tabular}{|l|l|l|}
\hline Core skills & Professional skills & $\begin{array}{l}\text { Communication } \\
\text { skills }\end{array}$ \\
\hline Integrity & $\begin{array}{l}\text { Knowledge of science } \\
\text { and engineering }\end{array}$ & $\begin{array}{l}\text { Written } \\
\text { communication }\end{array}$ \\
\hline Self-discipline & $\begin{array}{l}\text { Solution design as per } \\
\text { requirements }\end{array}$ & $\begin{array}{l}\text { Communication } \\
\text { in English }\end{array}$ \\
\hline Self-motivated & $\begin{array}{l}\text { Use of appropriate } \\
\text { tools/technologies }\end{array}$ & $\begin{array}{l}\text { Verbal } \\
\text { communication }\end{array}$ \\
\hline Team work & $\begin{array}{l}\text { Knowledge of } \\
\text { contemporary issues }\end{array}$ & \\
\hline
\end{tabular}

Four reviews are conducted for evaluation of miniproject and project. The project evaluation criteria are mapped to core employability skills, professional skills and communication skills. The marks are normalized to scale of 1 (lowest) to 5 (highest). Figure 5 and 6 shows the normalized results of employability skills for mini-project and project.

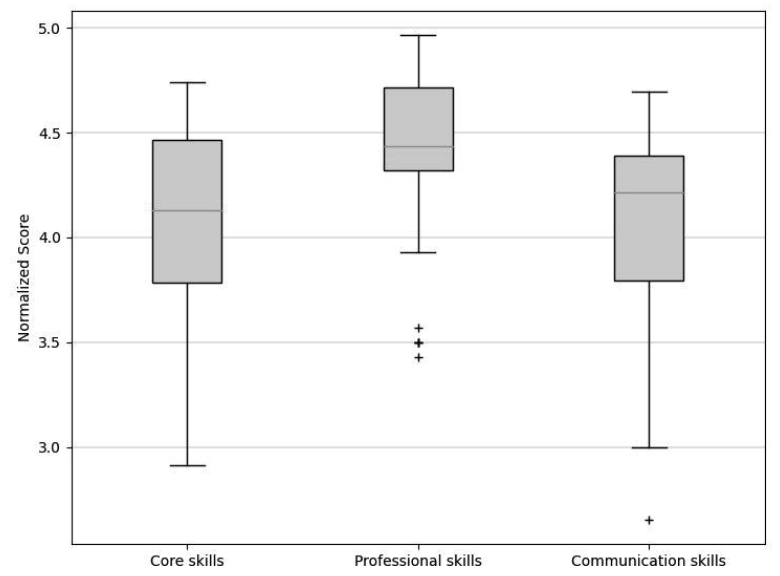

Fig. 5 : Skill-based evaluation result for mini-project

Results from figure 5 indicate that the overall performance of the entire third-year class is better with respect to considered employability skills. Median values for all three skill types are more than 4.2. More than $40 \%$ of students have shown outstanding performance on complex problem solving skills (professional skills) with more than 4.5 normalized score.

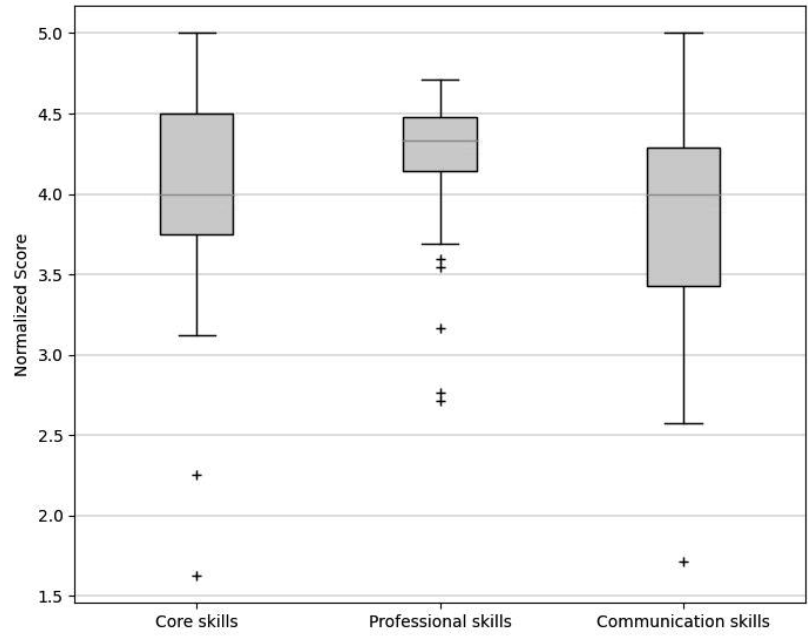

Fig. 6 : Skill-based evaluation results for project

Results from figure 6 indicate that the overall performance of the entire final year class is better with respect to considered employability skills. Median values for all three skill types are more than 4 . Students have shown better performance on complex problem-solving skills (professional skills) with normalized score between 4.2 and 4.5. Final year students calculated employability skill scores are validated with end result of students' selection for campus placement. Third-year students calculated employability skill scores are validated with their selection for industry internship program (IIP). To measure the accuracy of employability skill scores two measures are used.

- False bad score (FBS): Students' employability score is less but selected for campus placement (applicable for final year students) or industry internship program (applicable for third-year students).

- False good score (FGS): Students' employability score is good but not selected for campus placement (applicable for final year students) or industry internship program (applicable for thirdyear students).

Percentage of false bad score (FBS) and false good score (FBS) is approximately $10 \%$ and $18 \%$ respectively.

Placement is increased by $19 \%$ for batch $2015-19$ (92\%) as compared to batch 2014-18 (73\%).

Improvement in student problem-solving skills is satisfactory. For academic year highest packaged is 
offered to IT dept. is 8.5 lakh and average package of dept. is around 3.7 lakhs. Statistics show that for the academic year 2018-19 three students received inhouse funding around Rs. 30,000. Funding is given to promote students to convert academic projects into products.

Students completed online courses around 196 and it shows that they have improved in self-learning ability where students are having ability to learn from online courses/MOOCs/NPTL courses. Students are self-motivated to participate in national/international level competitions. Ten students' groups have participated in national level hackathon competitions and received the prizes. Seven students have been participated in summer internship in Asia University Taiwan and won first prize in project competition.

\section{Students feedback}

Batch 2015-19 students' feedback on use of active teaching-learning method is taken using five points Likert scale indicating 5 for strongly agree and 1 for strongly disagree. Student feedback at mid of semester is collected using sample questionnaire.

Table 10 shows the median of students' feedback values for selected three questions which are most relevant to proposed roadmap. Equal importance is given to each question and highest average is value 1.43. Table 10 shows that students are satisfied with the active teaching-learning planned in the proposed roadmap.

Table 10 : Median of student's feedback

\begin{tabular}{|c|c|c|c|c|c|c|c|c|c|c|c|c|c|}
\hline$\overbrace{\text { Questions }}^{\text {SLO's }}$ & SLO_1 & SLO_2 & SLO_3 & SLO_4 & SLO_5 & SLO_6 & SLO_7 & SLO_8 & SLO_9 & SLO_10 & SLO_11 & SLO_12 & SLO_13 \\
\hline $\begin{array}{l}\text { Are all course components and } \\
\text { Evaluations challenging }\end{array}$ & 1.33 & 1.00 & 1.25 & 1.25 & 1.27 & 1.08 & 1.08 & 1.20 & 1.20 & 1.13 & 1.14 & 1.19 & 1.11 \\
\hline $\begin{array}{l}\text { Are you given enough opportunities } \\
\text { for learning by doing }\end{array}$ & 1.33 & 1.02 & 1.26 & 1.26 & 1.23 & 1.12 & 1.12 & 1.18 & 1.18 & 1.14 & 1.19 & 1.19 & 1.04 \\
\hline
\end{tabular}

\section{Conclusions}

This paper proposed a roadmap to inculcate complex problem-solving knowledge and skills in CS/IT students. The proposed roadmap provides procedure to design student learning outcomes, suitable assessment method, curriculum and active teaching-learning activities for CS/IT department. The proposed roadmap provides a holistic way to department head, academic coordinator, syllabus designing committee and teacher for the effective teaching-learning process. The first step of roadmap describes the identification of student learning outcomes based on the mandatory requirements for employability and program outcomes. The second step provides an outcome-based evaluation strategy for assessment of student learning outcomes based on active learning techniques like project-based learning, problem-based learning and case studies. The third step focuses on designing a curriculum by identifying the most important courses to enhance the student's problem-solving skills during student engineering education. The fourth step recommends effective teaching-learning strategies for respective courses by identifying active learning-based topics.
Paper presents the implementation details of roadmap for batch 2015-19 CS\&IT department, RIT. The presented case study is guideline for identifying student learning outcomes, assessment methods, courses and active teaching-learning methods. The proposed roadmap focuses on identified SLOs and courses. It attempts Bloom's levels in incremental order from apply (third level) to create (fifth level). Results of batch 2015-19 show improved students' performance with higher level of Bloom's skills. Performance improvement is achieved in better results with highest and median marks. Results of employability skill score indicate the better performance with respect to core employability, professional and communication skills. Improvement in students' placement, industry-sponsored projects, participation in competitions and online certifications supports the success of roadmap.

The steps in roadmap are general and applicable to any science and engineering disciplines. Expert knowledge in respective discipline is necessary for the effective application of roadmap steps. There is future scope to prepare discipline-specific guidelines for 
effective application of proposed roadmap. Roadmap address planning, delivery and evaluation of dependent students learning outcomes. There is future scope to investigate the SLO attainment of dependent student learning outcomes.

\section{References}

[1] Adamuthe, A. C., \& Mane, S. U. (2016). Effective Outcome Based Assessment Methodology for Laboratory Course in Engineering Education. Journal of Engineering Education Transformations.

[2] Chinowsky, P. S., Brown, H., Szajnman, A., \& Realph, A. (2006). Developing knowledge landscapes through project-based learning. Journal of professional issues in engineering education and practice, 132(2), 118-124.

[3] Ellis, A., Carswell, L., Bernat, A., Deveaux, D., Frison, P., Meisalo, V., Meyer, J., Nulden, U., Rugeji, J., \& Tarhio, J. (1998, December). Resources, tools, and techniques for problembased learning in computing. In Working Group reports of the 3rd annual SIGCSE/SIGCUE ITiCSE conference on Integrating technology into computer science education (pp. 41-56). ACM.

[4] Evensen, D. H., Hmelo, C. E., \& Hmelo-Silver, C. E. (2000). Problem-based learning: A research perspective on learning interactions. Routledge.

[5] Fee, S. B., \& Holland-Minkley, A. M. (2010). Teaching computer science through problems, not solutions. Computer Science Education, 20(2), 129-144.

[6] Frank, M., Lavy, I., \& Elata, D. (2003). Implementing the project-based learning approach in an academic engineering course. International Journal of Technology and Design Education, 13(3), 273-288.

[7] Google play store . https://play.google.com/store/apps/developer?id $=$ Rajarambapu+Institute+Of+Technology, + Raj aramnagar\&hl=en

[8] Gülbahar, Y., \& Tinmaz, H. (2006). Implementing project-based learning and eportfolio assessment in an undergraduate course.
Journal of Research on Technology in Education, 38(3), 309-327.

[9] Hadim, H. A., \& Esche, S. K. (2002, November). Enhancing the engineering curriculum through project-based learning. In 32nd Annual Frontiers in Education (Vol. 2, pp. F3F-F3F). IEEE.

[10] Holmes, V. L., \& Hwang, Y. (2016). Exploring the effects of project-based learning in secondary mathematics education. The Journal of Educational Research, 109(5), 449-463.

[11] Hung, C. M., Hwang, G. J., \& Huang, I. (2012). A project-based digital storytelling approach for improving students' learning motivation, problem-solving competence and learning achievement. Journal of Educational Technology \& Society, 15(4), 368-379.

[12] Kay, J., Barg, M., Fekete, A., Greening, T., Hollands, O., Kingston, J. H., \& Crawford, K. (2000). Problem-based learning for foundation computer science courses. Computer Science Education, 10(2), 109-128.

[13] Mandale, R. J., \& Adamuthe, A. C. (2019, June). Skill Based Evaluation Technique for Software Development Projects in Higher Education. In National Conference on Exploring New Dimensions in Teaching-learning for Quality Education, KKWIEER, Nashik

[14] Mills, J.E., \& Treagust, D. F. (2003). Engineering education-Is problem-based or project-based learning the answer. Australasian journal of engineering education, 3(2), 2-16.

[15] Mustoe, L. R., \& Croft, A. C. (1999). Motivating engineering students by using modern case studies. International Journal of Engineering Education, 15(6), 469-476.

[16] Popil, I. (2011). Promotion of critical thinking by using case studies as teaching method. Nurse education today, 31(2), 204-207.

[17] Raju, P. K., \& Sankar, C. S. (1999). Teaching real-world issues through case studies. Journal of Engineering Education, 88(4), 501-508.

[18]Yadav, A., Lundeberg, M., DeSchryver, M., 
Dirkin, K., Schiller, N. A., Maier, K., \& Herreid, C. F. (2007). Teaching science with case studies: A national survey of faculty perceptions of the benefits and challenges of using cases. Journal of College Science Teaching, 37(1), 34.
[19] Yadav, A., Subedi, D., Lundeberg, M. A., \& Bunting, C. F. (2011). Problem-based learning: Influence on students' learning in an electrical engineering course. Journal of Engineering Education, 100(2), 253-280. 